\title{
Konseling Model Transteoritik dalam Perubahan Perilaku Merokok pada Remaja
}

\section{Counseling with the Transtheoritical Model in Changing Smoking Behavioral among Adolescents}

\author{
Adhitya Mardhika Saputra, Noni Mardeka Sary
}

\section{Program Studi Kependudukan Program Pascasarjana Universitas Sriwijaya Palembang}

\begin{abstract}
Abstrak
Perkembangan perokok di kalangan anak-anak dan remaja semakin meningkat, baik secara kuantitas maupun kualitas. Data Global Youth Tobacco Survey terakhir di tahun 2009, menunjukkan 20,3\% anak sekolah 13 - 15 tahun merokok. Perokok pemula usia $10-14$ tahun naik 2 kali lipat dalam 10 tahun terakhir dari 9,5\% pada tahun 2001 menjadi $17,5 \%$ pada tahun 2010. Angka perokok pada usia remaja yang tinggi meningkatkan risiko penyakit. Berdasarkan penelitian, para perokok yang terus merokok dalam jangka panjang memiliki risiko kematian tiga kali lebih tinggi daripada mereka yang bukan perokok. Individu mulai merokok disebabkan oleh pengaruh lingkungan sosial, seperti teman-teman, orang tua, dan media sehingga diperlukan suatu konseling terhadap remaja, salah satu metode konseling dengan pendekatan model transteoritik. Dalam beberapa kajian, terbukti model transteoritik efektif dalam mengubah perilaku merokok pada remaja. Berdasarkan kajian tersebut, diharapkan para konselor dalam memberikan konseling hendaknya memperhatikan kesiapan klien dalam mengubah perilaku hidupnya (aktivitas fisik) sesuai dengan tahap-tahapan yang ada dalam model transteoritik.
\end{abstract}

Kata kunci: Konseling, model transteoritik, perilaku merokok, remaja

\begin{abstract}
The quantitiy and quality of smoking habits in adolescents are rising, steadily. According to Data Global Youth Tobacco Survey in 2009, showed $20.3 \%$ of school children $13-15$ years were smoking. A beginner smokers aged 10 - 14 years increased 2-fold in the last 10 years from $9.5 \%$ in 2001 to $17.5 \%$ in 2010. High number of smokers in adolescence will increase the risk of disease. Based on studies, smokers who keep smoking in the long term would face the possibility of death three times higher than nonsmokers. People started to smoke because the influence of the social environment such as friends, parents, and the media thus needed a counseling to adolescents that is one with the approaches of counseling methods transtheoritical model (TTM).Transtheoritical models in several studies proved
\end{abstract}

effective in changing smoking behavior in adolescents. Based on the study isexpected to provide counselors should keep in readiness counseling clients in behavioral change his life (physical activity), it has been doing according to the stages in the transtheoritical model.

Keywords: Counseling, transtheoritical model, smoking behavior, adolescents

\section{Pendahuluan}

Di Indonesia, secara keseluruhan, jumlah perokok laki-laki dan perempuan naik 35\% pada 2012 dan merupakan yang terbesar se-Asia Tenggara. Jika dibandingkan dengan negara-negara ASEAN, konsumsi rokok di Indonesia mencapai 46,16\%. Kon sumsi rokok di beberapa negara, seperti di Malaysia hanya $2,90 \%$, Myanmar 8,73\%, Filipina 16,62\%, Vietnam 14,11\%, Thailand sekitar 7,74\%, Singapura 0,39\%, Laos 1,23\%, Kamboja 2,07\%, dan Brunei Darussalam 0,04\%. Berdasarkan data dari Lembaga Demografi Fakultas Ekonomi Universitas Indonesia, Southeast Asia Tobacco Control Alliance, dan Komisi Nasional Pengendalian Tembakau, Indonesia bahkan menduduki urutan ketiga jumlah perokok terbanyak di dunia setelah Cina dan India. Pada tahun 2012, di Indonesia terdapat 62,3 juta perokok. Meningkat dari 2011 dengan jumlah perokok sekitar 61,4 juta. ${ }^{1}$

Di kalangan remaja usia 15 - 19 tahun, sekitar 38,4\% laki-laki dan 0,9\% perempuan adalah perokok. Data Global Youth Tobacco Survey (GYTS) tahun

Alamat Korespondensi: Adithya Mardhika Saputra, Program Pascasarjana Universitas Sriwijaya Palembang, Jl. Padang Selasa No. 534 Palembang Sumatera Selatan, Hp.085249218400,e-mail: adhitya84@gmail.com 
2009, menunjukkan 20,3\% anak sekolah $13-15$ tahun telah merokok. Dalam sepuluh tahun terakhir, perokok pemula usia 10 - 14 tahun naik dua kali lipat dari $9,5 \%$ pada tahun 2001 menjadi $17,5 \%$ pada tahun $2010 .^{2}$ Usia tersebut adalah mereka yang duduk di kelas tiga SMP, SMA, dan awal kuliah. Umumnya kelompok tersebut adalah remaja yang mulai merokok untuk menunjukkan bahwa mereka sudah dewasa.

Namun, terdapat fakta yang mengejutkan, yaitu pada tahun 2010 terdapat sekitar $2,2 \%$ orang yang mulai merokok pada masa anak-anak usia 5 - 9 tahun berdasarkan data Riset Kesehatan Dasar (Riskesdas). ${ }^{3}$ Bahkan kita juga semua tahu bahwa beberapa anak balita sudah menjadi pecandu rokok. Kita tahu juga bahwa perokok aktif ini akan menjadi masalah pada orang sekitarnya yang tidak merokok. Mereka akan membuat orang di sekitar menjadi perokok pasif. Perlu penanganan dan upaya perlindungan terutama terhadap remaja perokok karena dampak rokok memang baru akan terasa pada 15 - 20 tahun mendatang. Ketika remaja berusia $10-14$ tahun sudah merokok, mereka akan menuai penyakit akibat rokok pada usia produktif. ${ }^{1}$

Sebagian besar perokok pemula adalah remaja yang belum mampu menilai secara benar informasi dampak merokok. Selain itu, kecenderungan perokok pemula untuk menyepelekan biaya yang kelak akan ditanggung akibat adiksi nikotin. Mereka menganggap bahwa biaya tersebut disebabkan oleh kelemahan perokok dewasa untuk memutuskan berhenti merokok ketika masih remaja. Mereka tidak menyadari efek adiktif nikotin yang sangat kuat yang akan mengikat dan menyebabkan orang sulit berhenti merokok. Merokok juga dianggap sebagai sesuatu yang biasa dan normal, sebagian perokok mengaku mendapat rokok dari keluarga atau teman dengan mudah tanpa perlu membeli. Selain itu, perokok remaja berpendapat bahwa merokok adalah sesuatu yang menarik, memudahkan pergaulan, mudah konsentrasi dan membuat hidup lebih mudah.

Perilaku merokok apabila dilihat dari berbagai sudut pandang sangat merugikan baik bagi individu yang bersangkutan maupun orang di sekeliling. Ada beberapa riset yang mendukung pernyataan tersebut. Jika dilihat dari sisi kesehatan, pengaruh bahan-bahan kimia yang dikandung rokok seperti nikotin, karbonmonoksida (CO), dan tar akan memacu kerja dari susunan saraf pusat dan susunan saraf simpatis sehingga mengakibatkan tekanan darah meningkat dan detak jantung bertabah cepat. ${ }^{4}$ Selain itu, rokok dapat menyebabkan penyakit bronkitis kronis, emfisema, kanker paru-paru, laring, mulut, faring, esofagus, kandung kemih, dan penyempitan pembuluh nadi. ${ }^{5}$

Perilaku merokok pada remaja umumnya semakin lama semakin meningkat sesuai dengan tahap perkem- bangan yang ditandai dengan peningkatan frekuensi dan intensitas merokok, dan sering mengakibatkan perokok mengalami ketergantungan nikotin. ${ }^{6}$

Individu pertama kali merokok pada usia $11-13$ tahun dan umumnya merokok pada usia sebelum 18 tahun. Seseorang yang pertama kali mengonsumsi rokok mengalami gejala-gejala seperti batuk-batuk, lidah terasa getir, dan perut mual. Namun, sebagian pemula yang mengabaikan gejala-gejala tersebut, berlanjut menjadi kebiasaan dan akhirnya menjadi ketergantungan yang dipersepsikan sebagai kenikmatan yang memberikan kepuasan psikologis. Gejala ini dapat dijelaskan dari konsep tobacco depency (ketergantungan rokok). Awalnya, merokok merupakan perilaku menyenangkan dan bergeser menjadi aktivitas yang bersifat obsesif karena sifat nikotin yang adiktif sehingga jika dihentikan secara tiba-tiba akan menimbulkan stres. ${ }^{8}$

Pada tahun 2020, rokok diperkirakan akan menjadi penyebab utama kematian dan kecacatan yang menewaskan lebih dari 10 juta orang setiap tahun, sekitar dua juta di antaranya terdapat di Cina. Oleh karena itu, rokok dapat menyebabkan lebih banyak kematian di seluruh dunia, lebih banyak dari gabungan kematian yang disebabkan HIV, TBC, kematian persalinan, kecelakaan lalu lintas, bunuh diri, dan pembunuhan. ${ }^{9}$ Satu dari dua perokok pada usia muda dan terus merokok seumur hidup dan akhirnya akan meninggal karena penyakit yang berhubungan dengan rokok. Rata-rata perokok yang memulai merokok pada usia remaja akan meninggal pada usia setengah baya, sebelum 70 tahun, atau kehilangan sekitar 22 tahun harapan hidup normal.

Ada berbagai alasan yang membuat seseorang mulai merokok, yaitu pengaruh lingkungan sosial, seperti teman-teman, orangtua, dan media. ${ }^{7}$ Pendapat lain menyatakan bahwa perilaku merokok merupakan fungsi lingkungan dan individu. ${ }^{4}$ Perilaku merokok selain disebabkan faktor-faktor dalam diri, juga disebabkan faktor lingkungan. Pada tahap awal, merokok dilakukan dengan teman-teman (46\%), anggota keluarga bukan orang tua $(23 \%)$, dan orang tua $(14 \%){ }^{7}$

Di kalangan mahasiswa, selain disebabkan oleh faktor adiktif, kebiasaan merokok dipicu oleh kondisi lingkungan yang mayoritas adalah perokok. Kebiasaan merokok yang turun-menurun, didukung oleh pemahaman yang kurang terhadap bahaya rokok terhadap kesehatan, menjustifikasi perilaku merokok mahasiswa. ${ }^{10}$ Ketergantungan terhadap produk tembakau sangat tepat apabila dianggap sebagai penyakit kronis dengan remisi dan relaps. Walaupun telah dilakukan intervensi minimal dan intensif untuk berhenti merokok, umumnya perokok yang menjalani program berhenti merokok akan kambuhan dan membutuhkan pengulangan intervensi sebelum akhirnya benar-benar berhasil berhenti merokok. ${ }^{11}$ Intervensi farmakologis 
yang dikombinasikan dengan konseling memungkinkan $20-25 \%$ perokok tetap berhenti merokok selama satu tahun setelah pengobatan. Proporsi keberhasilan tersebut sedikit lebih tinggi dari hasil studi pada perokok kelas menengah ke bawah di beberapa desa di Jawa Tengah, terapi kombinasi menghasilkan tingkat keberhasilan berhenti merokok selama 12 bulan sekitar 15\%.12 Oleh karena itu, untuk memberikan hasil yang lebih baik diperlukan konseling terhadap remaja, diperlukan upaya seperti metode konseling dengan model transteoritik.

\section{Model Transteoritik}

Beberapa individu perokok berusaha berhenti merokok melalui bantuan pengobatan yang diadakan instansi kesehatan pemerintah dan nonpemerintah. Bantuan pengobatan yang biasa digunakan instansi kesehatan dalam program rehabilitasi perokok untuk mengakhiri perilaku merokok memiliki tiga jenis pendekatan. Pertama, pendekatan perilaku (behavioral approaches) yang terdiri dari dua strategi, yaitu nonaversive strategies (seperti, pelatihan relaksasi, dukungan sosial, atau terapi penggantian nikotin) dan aversive strategies (seperti, rapid smoking, terapi sensitivitas kognitif, atau multimodal interventions). Kedua, pendekatan secara komunikasi verbal (verbal approaches), seperti terapi psikologis dan konseling. Terakhir, kampanye kepada suatu komunitas (community campaigns) tentang bahaya merokok dan usaha pencegahan agar perilaku merokok tidak semakin merambah ke generasi yang lebih muda, metode ini difokuskan terhadap teknik komunikasi atau berkampanye secara massal. ${ }^{13}$

Sekitar 90\% mantan perokok melaporkan bahwa mereka melakukan tanpa bantuan pengobatan khusus atau alat bantu berhenti merokok. Orang dewasa muda cenderung melakukan usaha berhenti merokok tanpa mengikuti intervensi penghentian dibandingkan dengan orang dewasa yang lebih tua. ${ }^{14}$ Tidak ada perbedaan yang signifikan antara individu yang memilih berhenti merokok tanpa bantuan dengan individu yang memilih untuk mengikuti program khusus. ${ }^{15}$

Proses perubahan berhenti merokok dapat diadaptasikan melalui enam tahapan perubahan perilaku melalui model transteoritik, yaitu teori yang menilai kesiapan individu untuk bertindak atau berperilaku sehat, dan membuat strategi atau proses-proses perubahan untuk membantu individu melalui tahapan perubahan ke tahap aksi dan pemeliharaan. ${ }^{16}$ Menurut teori ini, individu yang paling mungkin sukses mengubah perilaku adalah individu yang melakukan usaha berdasarkan strategi yang sesuai dengan tahap kesiapan untuk berubah. Dasar teori model transteoritik adalah perubahan perilaku merupakan suatu proses dan setiap orang berada pada tingkat yang berlainan ber- hubungan dengan motivasi dan kesiapan untuk berubah. Sehubungan dengan perilaku merokok, model ini mengidentifikasi lima tahapan kesiapan yang dapat diterapkan pada semua jenis perubahan perilaku. 16

Pertama, precontemplation yang dapat didefinisikan sebagai keadaan individu yang tidak mempunyai keinginan untuk mengubah perilaku. Kebanyakan individu pada tahap ini bahkan tidak sadar kalau mereka mempunyai masalah perilaku. Dengan demikian, individu pada tahap ini sangat sulit dimotivasi untuk mengubah perilaku. Sebagai contoh, seorang perokok menolak untuk mengakhiri perilaku merokok karena ia merasa tidak mempunyai masalah perilaku merokok yang ia pertahankan sehingga mereka tidak memiliki pemikiran atau pertimbangan untuk berhenti merokok.

Kedua, contemplation yaitu kondisi seseorang yang sadar atau mulai memikirkan keberadaan suatu masalah dari perilaku yang dipertahankan, tetapi belum membuat komitmen untuk bertindak. Pada tahap ini, seorang perokok mulai memikirkan suatu saat ia harus mengakhiri perilaku merokok karena berbagai efek negatif rokok mulai terasa karena belum dapat membuat suatu komitmen terhadap perilaku merokok, mereka akan mencari saat dan kondisi yang tepat untuk dapat memotivasi berhenti merokok. Proses perubahan yang terjadi pada tahap ini meliputi consciousness raising, yaitu kondisi individu yang menemukan dan mempelajari fakta baru, ide, dan tips yang mendukung perubahan menuju perilaku sehat; dramatic relief, yaitu merasakan perasaan negatif, seperti ketakutan atau kecemasan terhadap risiko pelaksanaan perilaku yang tidak sehat; environmental reevaluation, yaitu menyadari pengaruh negatif dari perilaku yang tidak sehat atau pengaruh positif dari perilaku sehat pada lingkungan sekitar individu; dan self-reevaluation, yaitu menyadari bahwa perubahan perilaku penting sebagai bagian dari identitas diri.

Ketiga, preparation, yaitu tahap ketika individu berniat mengubah perilaku dalam waktu dekat. Pada tahap ini perokok telah siap untuk berhenti. Proses perubahan yang terjadi pada tahap ini adalah self-liberation, individu membuat komitmen yang kuat untuk berubah. Pada beberapa kasus, perokok mulai membuat rencana berhenti seperti menentukan kapan akan berhenti atau mengurangi jumlah penggunaan rokok. Beberapa individu mulai memikirkan strategi yang dilakukan pada hari dia harus berhenti.

Keempat, action, sebagai tahap ketika individu mulai mengubah perilakunya untuk mengatasi masalah. Tindakan mengubah perilaku dan faktor-faktor yang mendukungnya membutuhkan suatu komitmen terhadap waktu dan energi. Kebanyakan individu akan membuktikan dirinya bahwa ia mampu mengakhiri perilaku merokok karena mereka telah mempersiapkan dirinya 


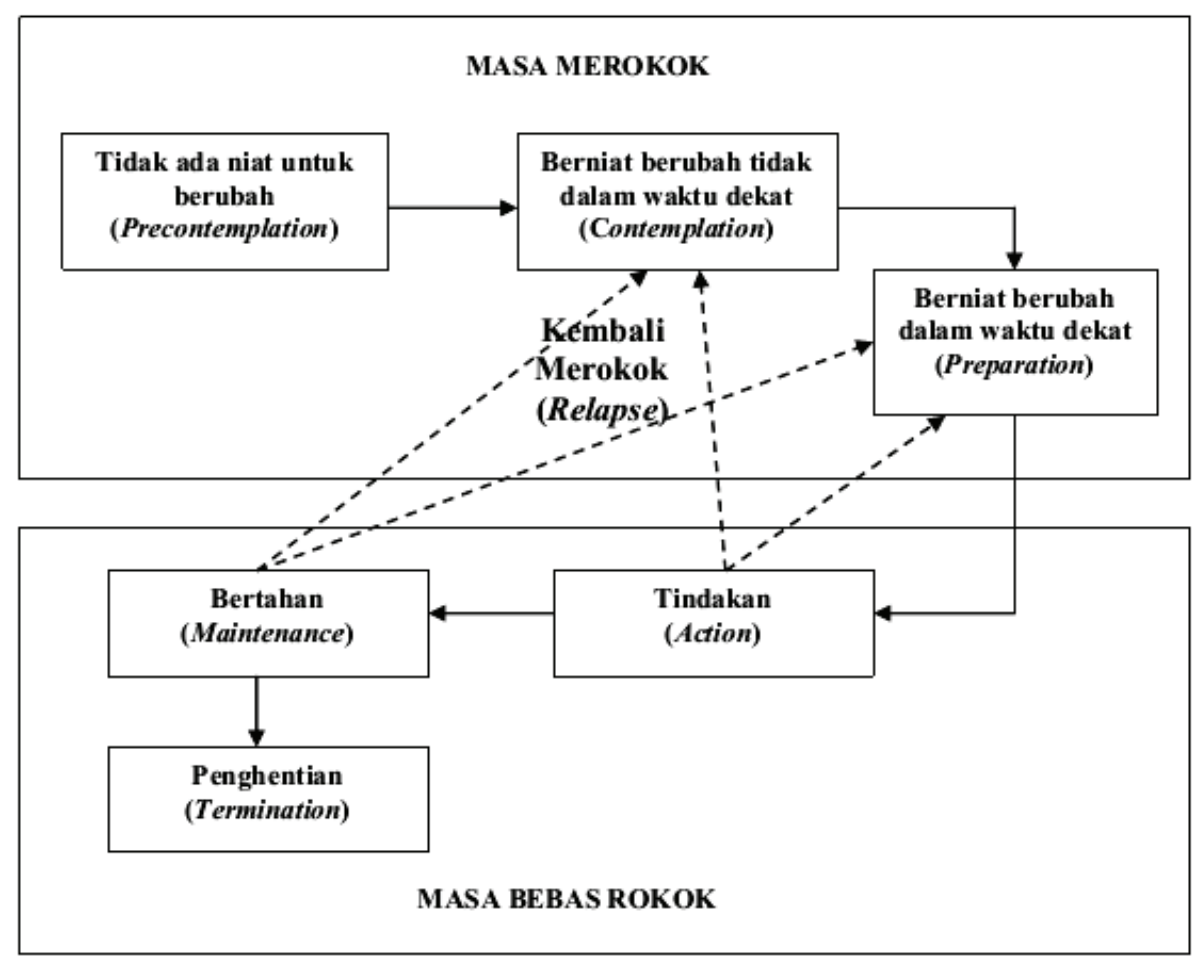

Gambar 1. Skema Perubahan Perilaku

dengan strategi-strategi untuk menghadapi dorongan untuk merokok kembali. Perokok telah mengambil tindakan untuk berhenti dan masih dalam enam bulan pertama dari masa bebas rokok. Tahap ini melibatkan beberapa proses perubahan perilaku, yaitu contingency management, yaitu meningkatkan penghargaan untuk perilaku baru yang sehat dan mengurangi penghargaan terhadap perilaku yang tidak sehat; helping relationships, yaitu mencari dan menggunakan dukungan sosial untuk perubahan perilaku sehat; counterconditioning, yaitu mengganti perilaku dan pemikiran yang tidak sehat dengan perilaku alternatif yang mendukung perubahan peri-laku; dan stimulus control, yaitu membuang pengingat yang dapat mengarahkan individu untuk terlibat dalam perilaku yang tidak sehat dan menambahkan pengingat yang mengarahkan pada perilaku sehat.

Kelima, maintenance, yaitu tahap ketika individu menjaga perubahan perilaku dari kemungkinan relapse (kembali ke perilaku yang telah ditinggalkan). Para perokok membandingkan keuntungan-keuntungan yang telah mereka peroleh dari berhenti merokok dengan sebuah keinginan untuk kembali merokok. Proses perubahan perilaku pada tahap ini sama dengan tahap action. Jika seseorang mampu tetap bebas dari perilaku adiktif lebih dari enam bulan, orang tersebut diasumsikan telah berada dalam tahap maintenance berhenti merokok. Begitu pula seseorang yang telah berhenti merokok tetapi masih berada pada tahun pertama masa bebas rokoknya.

Keenam, termination, merupakan tahap terakhir yang dapat diaplikasikan pada perilaku adiktif. Pada tahap ini, perilaku yang tidak sehat tidak akan pernah kembali dan individu tidak memiliki ketakutan akan kambuh. Meskipun individu tersebut merasa depresi, cemas, bosan, kesepian, marah, atau stres, mereka yakin bahwa mereka tidak akan kembali pada perilaku lama yang tidak sehat sebagai jalan penyelesaian masalah. Perilaku kambuh lagi atau relapse lebih merupakan aturan pada perilaku adiktif, maka transtheoritical model menggambarkan tahapan perubahan perilaku (Gambar 1). ${ }^{16}$

Gambar 1 merupakan skema yang menunjukkan tahapan perubahan perilaku. Tahap tersebut dimulai dari precontemplation, contemplation, preparation, action, maintenance, dan terakhir termination. Proses perubahan tersebut, pertama kali adalah individu yang semula sama sekali tidak berniat untuk berhenti merokok (precontemplation) mulai memikirkan pengaruh rokok terhadap dirinya dan berniat untuk berubah, tetapi tidak dalam waktu dekat (contemplation). Lalu saat niat berubah tersebut semakin kuat, dan seseorang yang mulai membentuk komitmen meninggalkan perilaku merokok (preparation) dalam waktu dekat akan mengambil tindakan berhenti merokok (action), kemudian mencoba untuk mempertahankan (maintenance) masa bebas rokok sehingga menjadi seorang yang berhasil meng- 
hentikan (termination) penggunaan rokok. Proses ini dapat berlangsung berulang-ulang jika individu tersebut mengalami relapse sehingga mereka dapat mempertahankan perilaku baru. Pengulangan siklus biasanya dimulai lagi pada tahap contemplation ataupun preparation, tergantung dari kondisi individu dan niat berhenti merokok.

Intervensi penanggulangan rokok dengan pendekatan personal kognitif semestinya lebih efektif dan sesuai dengan karakteristik sasaran. Intervensi melalui pemberian motivasi berdasarkan model transteoritik terbukti berpengaruh pada perokok kelompok usia remaja. Pemberian motivasi mampu mengubah secara positif perilaku merokok, bahkan sampai pada berhenti merokok. ${ }^{17}$ Selain itu, ada pengaruh rational bibliotherapy dengan The Transtheoritical Model of Behavior Change terhadap penurunan perilaku merokok. Keinginan yang kuat untuk selalu dapat diterima oleh kelompok seringkali justru menjadi tujuan utama yang mendorong remaja untuk tetap merokok. ${ }^{18}$ Untuk itu, informasi tentang gangguan atau risiko yang dapat dialami perokok sangat diperlukan untuk mengubah persepsi mereka tentang perilaku merokok dan segala akibatnya.

\section{Kesimpulan}

Masalah merokok adalah masalah global yang terlalu besar untuk ditangani secara terpisah. Penghentian perilaku merokok remaja berpotensi besar untuk menyelamatkan banyak nyawa dan memberikan kesempatan hidup yang lebih baik. Upaya-upaya yang dilakukan untuk menghentikan perilaku merokok pada remaja akan memberikan beberapa pelajaran berharga untuk direnungkan saat kita mempertimbangkan bentuk intervensi yang efektif. Tidak peduli, pendekatan yang bersifat individual, kelompok atau intervensi komunitas merupa-kan investasi yang baik. Suatu pendekatan yang komprehensif perlu dilakukan untuk mencapai keberhasilan yang lebih besar. Perubahan besar dalam status kesehatan remaja dengan kehidupan tanpa rokok akan terjadi. Apa norma-norma sosial berhubungan dengan pemakaian dan perilaku merokok perlu diubah. Hal ini membutuhkan waktu yang tidak singkat. Mengubah perilaku remaja melalui konseling merupakan salah satu upaya untuk mengintervensi remaja. Pemberian konseling tersebut akan lebih efektif, semua yang dilakukan dengan pendekatan model transteoritik, memperhatikan kesiapan klien untuk menerima informasi dan mengubah perilaku.

\section{Saran}

Para konselor diharapkan dapat memberikan konseling kepada para remaja. Teknik dan informasi yang diberikan harus sesuai dengan kesiapan klien dan kriteria klien berdasarkan tahapan pada model transteoritik.

\section{Ucapan Terima Kasih}

Ucapan terima kasih disampaikan kepada pihakpihak yang telah membantu terlaksananya penulisan artikel ini yaitu Tatang A. M. Sariman, M.A., Ph.D. dan Dr. Lili Erina, M.Si. selaku dosen pembimbing.

\section{Daftar Pustaka}

1. Fitria AG. Perokok Indonesia terbanyak se-Asia Tenggara [Diakses tanggal 9 Januari 2014]. Diunduh dari: http://www.tempo.co/read/news/2013/10/10/090520749/Perokok-Indonesia-Terbanyak-se-AsiaTenggara.

2. Mulyana A. Ini bocoran kementerian kesehatan soal jutaan perokok anak remaja di Indonesia [Diakses tanggal 9 Agustus 2013]. Diunduh dari: http://www.rmol.co/read/2013/11/12/132873/Ini-BocoranDirjen-Kemenkes-Soal-Jutaan-Perokok-Anak-Remaja-di-Indonesia-.

3. Syam AF. Satu dari tiga orang Indonesia merokok [Diakses tanggal 10 September 2013]. Diunduh dari: http://www.readersdigest.co.id/ sehat/info.medis/1.dari.3.orang.indonesia.merokok/005/001/187.

4. Komalasari D, Helmi AF. Faktor-faktor penyebab perilaku merokok pada remaja. Jurnal Psikologi. 2000; 28: 37-47.

5. Susanna D, Budi H, Hendra F. Penentuan kadar nikotin dalam asap rokok. Jurnal Kesehatan. 2003; 7: 47-9.

6. Gee Mc. Is cigarette smoking associated with suicidal ideation among young people. The American Journal of Psychiatry. 2005; 162: 619-20.

7. Smet B. Psikologi kesehatan. Jakarta: PT Grasindo; 1994.

8. Tandra H. Smoking and health [Diakses tanggal 9 Agustus 2013]. Diunduh dari: http://healthinsidefreshoutside.blogspot.com/2010/04/merokok-dan-kesehatan.html

9. Universitas Gadjah Mada. Mengapa remaja merokok. Yogyakarta: Universitas Gadjah Mada Press; 2004 [Diakses tanggal 9 Agustus 2013]. Diunduh dari: http://www.mqmedia.com/tabloid_mq/apr03/mq_remaja_pernik.htm.

10. Rosemary R. Antara motivasi dan tantangan berhenti merokok (studi kasus mahasiswa di Banda Aceh). Malaysia: Aceh Development International Conference; 2011.

11. U.S. Department of Health and Human Services. Reducing tobacco use: a report of the surgeon general-executive summary. Atlanta, Georgia: U.S. Department of Health and Human Services, Centers for Disease Control and Prevention, National Center for Chronic Disease Prevention and Health Promotion, Office on Smoking and Health; 2000.

12. Yurekli AA, Dewi FST, de Bayer J, Cornelia AH, Hennen J. New ways of helping poor smokers to quit in Central Java, Indonesia. Economics Tobaccoontrol Paper. Washington: The World Bank; 2004.

13. Oskamp S, Schultz W. Applied social psychology. London: Prenticehall; 1998.

14. Curry SJ, Grothaus L, McBride C. Reasons for quitting: intrinsic and extrinsic motivation for smoking cessation in a population-bases sample of smokers. Addictive behaviors. 1997; 22 (6): 727-39.

15. Sheridan R. Health psychology: challenging the biomedical model. Canada: John Willey \& Sons Inc; 1992.

16. ProchaskaJO, Velicer WF. The transtheoretical model of health behavior change. American Journal of Health Promotion. 1997; 12: 38-48.

17. Saime E, Semra E. Application of a stage based motivational interview- 
Saputra \& Sary, Konseling Model Transtheoritik dalam Mengubah Perilaku Merokok pada Remaja

ing approach to adolescent smoking cessation: the transtheoretical model-based study. Patient Education and Counseling. 2004; 72: 42-8.

18. Lasmono KH, Novitawati M, Rahayu S. Pengaruh rational bibliothera- py terhadap penurunan perilaku merokok dengan the transtheoritical model of behavior change sebagai acuan pengukuran. Anima Indonesian Psychological Journal. 2001; 16(3): 252-71. 